PACS: 61.50.Ah, 62.25.-g, 62.20.dj

\title{
Mechanical characteristics for seven-constant rhombohedral crystals and their nano/microtubes
}

\author{
R.V. Goldstein ${ }^{\dagger}$, V.A. Gorodtsov, D.S. Lisovenko, M.A. Volkov \\ †goldst@ipmnet.ru
}

Ishlinsky Institute for Problems in Mechanics RAS, pr. Vernadskogo 101, b1, Moscow, 119526, Russia

\begin{abstract}
Stretching 7-constant rhombohedral crystals is described in the theory of elasticity. Numerical analysis, based on the obtained analytical expressions for Young's modulus and Poisson's ratio, is showed that three of the eight 7-constant rhombohedral crystals are partial auxetics, i.e. they have a negative Poisson's ratio in some directions of stretching crystals. Minimum and maximum values of Poisson's ratio and Young's modulus, values of the average Poisson's ratio and the minimum and maximum values of Poisson's ratio for particular orientations were obtained. Auxetic surfaces corresponding to zero Poisson's ratio were plotted. Solution of problems of tension and torsion curvilinear anisotropic nano/microtubes from 7-constant rhombohedral crystals was considered under Saint-Venant's approach. Analytical expressions of Young's modulus and Poisson's ratio for these nano/microtubes were obtained. Numerical analysis allowed to find six of the eight auxetics among nano/microtubes. Values of Poisson's ratio for thin-walled nano/ microtubes from 7-constant rhombohedral crystals, as well as critical values of thickness parameter at which the change in the sign of Poisson's ratio were obtained. It is shown that Young's modulus slightly dependent on the thickness parameter of the tube. An analytical expression for the torsional stiffness of nano/microtubes from 7-constant rhombohedral crystals were obtained. The numerical values of the coefficient characterizing the torsional stiffness of nano/microtubes of 7-constant rhombohedral crystals were given. It is found that the influence of the chirality angle on the mechanical characteristics of nano/microtubes from 7-constant rhombohedral crystals in the case of the direct and inverse Poynting's effect unlike tubes from orthorhombic and tetragonal crystals are absent.
\end{abstract}

Keywords: rhombohedral crystals, nanotubes, microtubes, auxetics, stretching, twisting.

\section{Механические характеристики 7-ми константных ромбоэдрических кристаллов и нано/микротрубок из них}

\author{
Гольдштейн Р.В. ${ }^{\dagger}$, Городцов В.А., Лисовенко Д.С., Волков М.А. \\ †goldst@ipmnet.ru
}

Институт проблем механики им. А.Ю. Ишлинского РАН, Москва, пр. Вернадского, д.101, корп.1, 119526, Россия

В рамках теории упругости дано описание растяжения 7-ми константных ромбоэдрических кристаллов. Численный анализ, основанный на полученных аналитических выражениях для модуля Юнга и коэффициента Пуассона, показал, что три из восьми 7-ми константных ромбоэдрических кристаллов являются частичными ауксетиками, т.е. имеют отрицательный коэффициент Пуассона при некоторых направлениях растяжения кристаллов. Определены минимальные и максимальные значения коэффициентов Пуассона и модулей Юнга, значения среднего коэффициента Пуассона, а также минимальные и максимальные значения коэффициента Пуассона при частных ориентациях. Построены поверхности ауксетичности, соответствующие нулевому коэффициенту Пуассона. Рассмотрено решение задач о растяжении и кручении криволинейно-анизотропных нано/микротрубок из 7-ми константных ромбоэдрических кристаллов в рамках подхода Сен-Венана. Получены аналитические выражения модуля Юнга и коэффициента Пуассона для таких нано/микротрубок. Численный анализ позволил обнаружить шесть из восьми ауксетиков среди нано/микротрубок. Определены значения коэффициентов Пуассона для тонкостенных нано/микротрубок из 7-ми константных ромбоэдрических кристаллов, а также критические значения параметра толщины, при котором происходит смена знака коэффициента Пуассона. Показано, что модуль Юнга слабо зависит от параметра толщины трубки. Получено аналитическое выражение для крутильной жесткости нано/микротрубок из 7-ми константных ромбоэдрических кристаллов. Приведены численные значения коэффициента, характеризующего крутильную жесткость нано/микротрубок из 7-ми константных ромбоэдрических кристаллов. Установлено отсутствие влияния угла хиральности на механические характеристики нано/микротрубок из 7-ми константных ромбоэдрических кристаллов и прямого и обратного эффекта Пойнтинга в отличие от трубок из орторомбических и тетрагональных кристаллов.

Ключевые слова: ромбоэдрические кристаллы, нанотрубки, микротрубки, ауксетики, растяжение, кручение. 


\section{Introduction}

The isotropic materials with a negative Poisson's ratio (auxetics) were first discovered by the examples of metal and polymer foams [1,2]. This occurs more often among the anisotropic materials, for example, among the crystals of all crystalline systems and, in particular, for cubic crystals [3-15] and rhombohedral (trigonal) crystals and their microtubes and nanotubes [9, 16-18]. Below, we analyze the rectilinearly anisotropic elasticity for 7-constant rhombohedral crystals and the curvilinearly anisotropic elasticity for their nano/microtubes, using experimental data on the elastic coefficients from [19].

\section{Auxetics among rectilinearly- anisotropic rhombohedral crystals}

Small deformations of rectilinearly-anisotropic elastic body are described by means of Hooke's law $\varepsilon_{i j}=s_{i j k l} \sigma_{k l}$ - linear relationship between the stress tensor and the strain tensor with the tensor compliance coefficients $s_{i j k l}$. Young's modulus and Poisson's ratio in uniaxial tension of the crystal in the direction of the unit vector $\mathbf{n}$ are determined by the following expressions (see [20])

$$
\frac{1}{E(\mathbf{n})}=s_{i j k l} n_{i} n_{j} n_{k} n_{l}, \quad v(\mathbf{n}, \mathbf{m})=\frac{s_{i j k l} m_{i} m_{j} n_{k} n_{l}}{s_{q r s t} n_{q} n_{r} n_{s} n_{t}},
$$

Here, $m_{i}$ - the components of the unit vector $\mathbf{m}$, perpendicular to $\mathbf{n}$.

The matrix of compliance coefficients for 7-constant rhombohedral crystals looks according to [21] as follows

$$
\left(\begin{array}{cccccc}
s_{11} & s_{12} & s_{13} & s_{14} & s_{15} & 0 \\
s_{12} & s_{11} & s_{13} & -s_{14} & -s_{15} & 0 \\
s_{13} & s_{13} & s_{33} & 0 & 0 & 0 \\
s_{14} & -s_{14} & 0 & s_{44} & 0 & -2 s_{15} \\
s_{15} & -s_{15} & 0 & 0 & s_{44} & 2 s_{14} \\
0 & 0 & 0 & -2 s_{15} & 2 s_{14} & 2\left(s_{11}-s_{12}\right)
\end{array}\right)
$$

and connections $s_{11}=s_{1111}, s_{33}=s_{3333}, s_{44}=4 s_{2323}, s_{12}=s_{1122}$, $s_{14}=2 s_{1123}, s_{15}=2 s_{1113}$ take place between the matrix components and the above tensor components. A parameterization of stretching direction by Euler's angles $\varphi, \theta, \psi$, and this matrix allows to write Young's modulus and Poisson's ratio in the form of periodic functions of the Euler angles with periods of $\mathrm{T}_{\varphi}=2 \pi, \mathrm{T}_{\theta}=\pi$ and $\mathrm{T}_{\varphi}=2 \pi, \mathrm{T}_{\theta}=2 \pi, \mathrm{T}_{\psi}=\pi$, respectively.

Numerical analysis of these angular dependences with using of experimental data on the matrix compliance coefficients, given in [19], reveals that three of eight 7-constant rhombohedral crystals are partial auxetics, i.e. they have negative Poisson's ratio in some directions of stretching crystals (Table 1). Extreme and average values of Poisson's ratio are presented in this table. In addition, the maximum and minimum values for three particular orientations are indicated. The numbers in case of coincidence of local extrema (at particular orientations) and global extrema are written in bold. The average values of Poisson's ratio for all crystals are positive and vary in the range of $0.10-0.32$.

The surfaces of zero Poisson's ratio ("the surfaces of auxeticity") $v(\varphi, \theta, \psi)=0$ divide regions of the negative and positive coefficients for partial auxetics. Such surfaces for two auxetic crystals $\mathrm{MgSiO}_{3}, \mathrm{CaMg}\left(\mathrm{CO}_{3}\right)_{2}$ refer to "closed" type, and for auxetic crystal SbI to the "open" type (Fig. 1) due to a periodicity of the angular cells.

The calculated global extrema of Young's modulus for the rhombohedral crystals are shown in Table 2. Two crystal $\mathrm{Be}_{2} \mathrm{SiO}_{4}, \mathrm{MgSiO}_{3}$ have the highest values of Young's modulus $\left(E_{\min }>220 \mathrm{GPa}\right)$. We note that the data on the elastic constants of the crystal $\mathrm{BiI}_{3}$ are presented in [19] at low temperature (83K).

\section{From rectilinearly-anisotropic crystals to curvilinearly-anisotropic nano/ \\ microtubes. Problems of tension and torsion of rhombohedral nano/microtubes}

Many nanomaterials are synthesized in the form of nanotubes [22-23]. Successful technology for creating the nanotubes and microtubes by rolling up thin plates must be marked especially [24-26]. Preparation of nano/microtubule by such a way is possible practically from all crystalline materials.

Rolling up a rectilinearly anisotropic plate creates curvilinearly-anisotropic tube. We assume that prior to

(a)

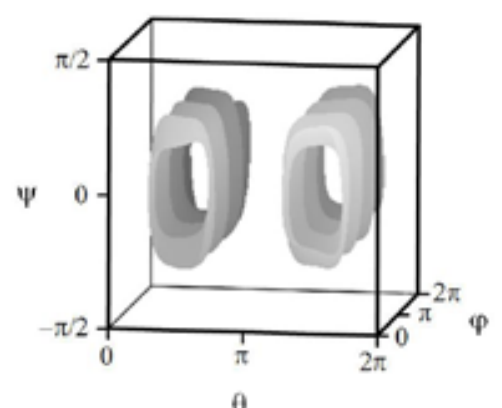

(b)

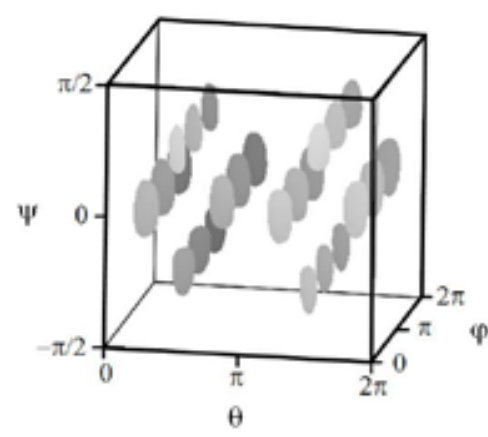

(c)

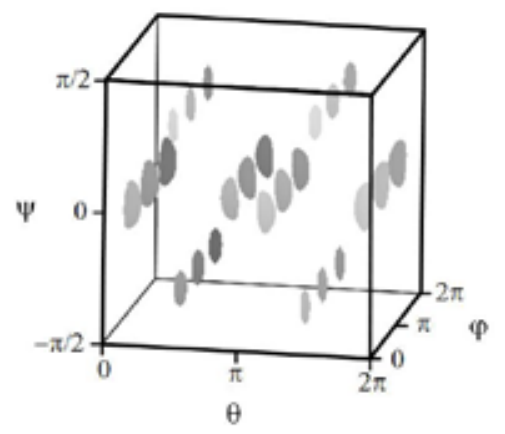

Fig. 1. The auxeticity surfaces $v(\varphi, \theta, \psi)=0$ for crystals $\mathrm{SbI}_{3}$ (a), $\mathrm{CaMg}\left(\mathrm{CO}_{3}\right)_{2}$ (b) и $\mathrm{MgSiO}_{3}$ (c). 
Table 1. Extreme and average values of Poisson's ratio.

\begin{tabular}{|c|c|c|c|c|c|c|c|c|}
\hline \multirow{2}{*}{ Crystals } & \multirow{2}{*}{$v_{\text {min }}$} & $v_{\max }$ & $<v>$ & \multicolumn{2}{|c|}{ at $n_{1}=1$} & \multicolumn{3}{|c|}{ at $n_{2}=1$} \\
\cline { 5 - 9 } & & & $v_{\min }$ & $v_{\max }$ & \multicolumn{2}{|c}{$v_{\min }$} & $v_{\max }$ & at $n_{3}=1$ \\
\hline $\mathrm{SbI}_{3}$ & -0.60 & 0.71 & 0.10 & -0.44 & 0.62 & -0.46 & 0.62 & 0.40 \\
\hline $\mathrm{Be}_{2} \mathrm{SiO}_{4}$ & 0.22 & 0.37 & 0.28 & 0.23 & 0.34 & 0.22 & 0.35 & 0.28 \\
\hline $\mathrm{BiI}_{3}(83 \mathrm{~K})$ & $\mathbf{0 . 0 1}$ & 0.47 & 0.23 & $\mathbf{0 . 0 1}$ & 0.40 & 0.10 & 0.31 & 0.27 \\
\hline $\mathrm{Ce}_{2} \mathrm{Mg}_{3}\left(\mathrm{NO}_{3}\right)_{12} \cdot 24 \mathrm{H}_{2} \mathrm{O}$ & 0.17 & 0.54 & 0.32 & 0.21 & 0.42 & 0.20 & 0.43 & 0.38 \\
\hline $\left.\mathrm{CaMg}_{2} \mathrm{CO}_{3}\right)_{2}$ & -0.07 & 0.73 & 0.30 & 0.01 & 0.66 & 0.10 & 0.57 & 0.21 \\
\hline $\mathrm{Pb}_{4.7} \mathrm{Ba}_{0.3} \mathrm{Ge}_{3} \mathrm{O}_{11}$ & $\mathbf{0 . 1 5}$ & $\mathbf{0 . 3 4}$ & 0.25 & $\mathbf{0 . 1 5}$ & $\mathbf{0 . 3 4}$ & $\mathbf{0 . 1 5}$ & $\mathbf{0 . 3 4}$ & 0.21 \\
\hline $\mathrm{Pb}_{5} \mathrm{Ge}_{3} \mathrm{O}_{11}$ & $\mathbf{0 . 1 3}$ & $\mathbf{0 . 3 4}$ & 0.25 & $\mathbf{0 . 1 3}$ & $\mathbf{0 . 3 4}$ & $\mathbf{0 . 1 3}$ & $\mathbf{0 . 3 4}$ & 0.20 \\
\hline $\mathrm{Pb}_{5} \mathrm{Ge}_{3} \mathrm{O}_{11}, s^{E}$ & $\mathbf{0 . 1 2}$ & $\mathbf{0 . 3 7}$ & 0.25 & $\mathbf{0 . 1 2}$ & 0.36 & $\mathbf{0 . 1 2}$ & $\mathbf{0 . 3 7}$ & 0.19 \\
\hline $\mathrm{MgSiO}_{3}$ & 0.12 & 0.37 & 0.25 & 0.12 & 0.36 & 0.12 & 0.37 & 0.19 \\
\hline & -0.02 & 0.51 & 0.25 & 0.03 & 0.63 & 0.04 & 0.45 & 0.11 \\
\hline
\end{tabular}

Table 2. Extreme values of Young's modulus.

\begin{tabular}{|c|c|c|}
\hline Crystals & $\begin{array}{c}E_{\min }, \\
\mathrm{GPa}\end{array}$ & $\begin{array}{c}E_{\max } \\
\mathrm{GPa}\end{array}$ \\
\hline $\mathrm{SbI}_{3}$ & 6.10 & 15.2 \\
\hline $\mathrm{Be}_{2} \mathrm{SiO}_{4}$ & 236 & 316 \\
\hline $\mathrm{BiI}_{3}(83 \mathrm{~K})$ & 16.8 & 27.1 \\
\hline $\mathrm{Ce}_{2} \mathrm{Mg}_{3}\left(\mathrm{NO}_{3}\right)_{12} \cdot 24 \mathrm{H}_{2} \mathrm{O}$ & 14.6 & 25.5 \\
\hline $\left.\mathrm{CaMg}_{2} \mathrm{CO}_{3}\right)_{2}$ & 70.2 & 192 \\
\hline $\mathrm{Pb}_{4.7} \mathrm{Ba}_{0.3} \mathrm{Ge}_{3} \mathrm{O}_{11}$ & 54.8 & 80.0 \\
\hline $\mathrm{Pb}_{5} \mathrm{Ge}_{3} \mathrm{O}_{11}$ & 54.9 & 87.0 \\
\hline $\mathrm{Pb}_{5} \mathrm{Ge}_{3} \mathrm{O}_{11}, s^{E}$ & 52.5 & 87.7 \\
\cline { 2 - 3 } & 51.8 & 86.2 \\
\hline $\mathrm{MgSiO}_{3}$ & 226 & 434 \\
\hline
\end{tabular}

rolling a rhombohedral crystal rotates around the main axis (3) at an angle $\chi$. This leads to a change in the two matrix compliance coefficients

$$
\begin{aligned}
& s_{14}^{\prime}=s_{14} a(\chi)+s_{15} b(\chi), \quad s_{15}^{\prime}=s_{15} a(\chi)-s_{14} b(\chi), \\
& a(\chi) \equiv 4 \cos ^{3} \chi-3 \cos \chi, \quad b(\chi) \equiv 4 \sin ^{3} \chi-3 \sin \chi .
\end{aligned}
$$

The tube of cylindrically-anisotropic elasticity will correspond to the rotated plate, and Hooke's law has the form, respectively

$$
\begin{gathered}
u_{z z}=s_{11} \sigma_{z z}+s_{12} \sigma_{\varphi \varphi}+s_{13} \sigma_{r r}-s_{14} \sigma_{r \varphi}+s_{15} \sigma_{r z}, \\
u_{\varphi \varphi}=s_{12} \sigma_{z z}+s_{11} \sigma_{\varphi \varphi}+s_{13} \sigma_{r r}+s_{14} \sigma_{r \varphi}-s_{15} \sigma_{r z}, \\
u_{r r}=s_{13}\left(\sigma_{z z}+\sigma_{\varphi \varphi}\right)+s_{33} \sigma_{r r}, \\
2 u_{r z}=s_{15}^{\prime}\left(\sigma_{z z}-\sigma_{\varphi \varphi}\right)+s_{44} \sigma_{r \varphi}-2 s_{14}^{\prime} \sigma_{\varphi z}, \\
-2 u_{r \varphi}=s_{14}^{\prime}\left(\sigma_{z z}-\sigma_{\varphi \varphi}\right)-s_{44} \sigma_{r \varphi}+2 s_{15}^{\prime} \sigma_{\varphi z}, \\
-2 u_{\varphi z}=2 s_{15}^{\prime} \sigma_{r \varphi}+2 s_{14}^{\prime} \sigma_{r z}-s_{66} \sigma_{\varphi z} .
\end{gathered}
$$

If we consider the problem of a longitudinal tension of the hollow circular tube under the influence of specific momentless force applied to the ends, in the absence of stress

on the lateral surfaces of the inner and outer radii $r_{0}$ and $R_{0}=\rho r_{0}$

$$
\begin{gathered}
P S=\int \sigma_{z z} d S, \quad M_{z}=\int \sigma_{\varphi z} r d S=0, \\
\left.\sigma_{i r}\right|_{r=r_{0}}=\left.\sigma_{i r}\right|_{r=R_{0}}=0,
\end{gathered}
$$

so axially symmetric non-uniform radial stress distribution has properties $\sigma_{r \varphi}(r)=0, \sigma_{r z}(r)=0$. Simplified relations of Hooke's law and the equation of equilibrium lead to unambiguous displacements and, ultimately, to the normal stress $\sigma_{r r}(r)$

$$
\begin{aligned}
& \sigma_{r r}(r)=\frac{s_{13}-s_{12}}{s_{11}^{2}+s_{13}^{2}-s_{12}^{2}-s_{11} s_{33}} \varepsilon+\varepsilon \sum_{ \pm} A_{ \pm} r^{\lambda_{ \pm}}, \\
& \lambda_{ \pm}=-1 \pm k, \quad k \equiv \sqrt{\left(s_{11} s_{33}-s_{13}^{2}\right) /\left(s_{11}^{2}-s_{12}^{2}\right)}
\end{aligned}
$$

and to other normal stresses similarly. The shear stress $\sigma_{\varphi z}(r)=\tau r /\left(2 s_{11}-2 s_{12}\right)$ in the absence of torque disappears together with torsion angle. Hence, extension nano/ microtubes from rhombohedral crystals is not accompanied by twisting. Direct Poynting's effect is absent. The absence of normal stress $\sigma_{r r}(r)$ on the sides of the tube provides for $\mathrm{A}_{+}, \mathrm{A}_{-}$

$$
A_{ \pm}=\sum_{ \pm} \frac{1-\rho^{-\lambda_{\mp}}}{\rho^{\lambda_{ \pm}-\lambda_{\mp}}-1}, \quad \Lambda \equiv \frac{s_{13}-s_{12}}{s_{11}^{2}+s_{13}^{2}-s_{12}^{2}-s_{11} s_{33}} .
$$

Young's modulus is determined by the normal stress $\sigma_{z z}(r)$

$$
E=\frac{1}{s_{11}}\left(1-\Lambda-2 \sum_{ \pm} \frac{s_{13} \pm k s_{12}}{\lambda_{ \pm}+2} A_{ \pm} \frac{\rho^{\lambda_{ \pm}+2}-1}{\rho^{2}-1}\right) .
$$

Poisson's ratio defined by the ratio of transverse strain to the longitudinal one

$$
\begin{aligned}
& v_{r z}=-\frac{1}{s_{11}}\left[s_{13}+\alpha_{1} \Lambda+\sum_{ \pm} \alpha_{ \pm k} A_{ \pm}\left(\frac{r}{r_{0}}\right)^{\lambda_{ \pm}}\right], \\
& v_{\varphi z}=-\frac{1}{s_{11}}\left[s_{12}+\beta_{1} \Lambda+\sum_{ \pm} \beta_{ \pm k} A_{ \pm}\left(\frac{r}{r_{0}}\right)^{\lambda_{ \pm}}\right], \\
& \alpha_{q} \equiv s_{11} s_{33}-s_{13}^{2}+q s_{13}\left(s_{11}-s_{12}\right), \\
& \beta_{q} \equiv q\left(s_{11}^{2}-s_{12}^{2}\right)+s_{13}\left(s_{11}-s_{12}\right), \quad q=1, \pm k .
\end{aligned}
$$


They are dependent on the compliance coefficients (except $s_{14}^{\prime}, s_{15}^{\prime}$ ), the dimensionless radial coordinate $r / r_{0}$ and the relationship of external and internal radii $\rho$.

The linear radial dependence of the shear stress leads to a simple result for the torsional rigidity in the case of a torsion problem for nano/microtubes

$$
C=\frac{M_{z}}{\tau}=\frac{1}{\tau} \int \sigma_{\varphi z}(r) r d S=\alpha r_{0}^{4}\left(\rho^{4}-1\right), \quad \alpha \equiv \frac{\pi}{4\left(s_{11}-s_{12}\right)} .
$$

The results of numerical estimates of Poisson's ratio for the nano/microtubes with experimental data on compliance coefficient for rhombohedral crystals from [19] are presented in Table 3. This table includes results for the thin-walled tubes $((\rho-1) \ll 1)$ and critical thickness parameter $\rho_{c r}$ at which Poisson's ratio is zero. It can be seen that the six tubes are auxetics. Figure 2 illustrates the variation of Poisson's ratios with changes in the thickness parameter.

The numerical values of Young's modulus (in GPa) for thin-walled tubes with the $(\rho-1) \ll 1$ and for thick-walled tubes with thickness parameter $\rho=10$ shown in Table 4 . Influence of thickness parameter on Young's modulus of nano/microtubes is insignificant. The highest Young's moduli have nano/microtubes from crystals $\mathrm{Be}_{2} \mathrm{SiO}_{4}$ and $\mathrm{MgSiO}_{3}$ $\left(E_{\text {min }}>250 \mathrm{GPa}\right)$.

The numerical values of coefficient $\alpha$ which characterizes the torsional rigidity of nano/microtubes of rhombohedral crystals are shown in Table 5. It is clear from this table that we have the highest torsional stiffness among nano/microtubes from crystals $\mathrm{Be}_{2} \mathrm{SiO}_{4}$ and $\mathrm{MgSiO}_{3}$.

\section{Conclusion}

The analysis showed that among the eight rectilinearlyanisotropic 7-constant rhombohedral crystals are three auxetics $\mathrm{SbI}_{3}, \mathrm{CaMg}\left(\mathrm{CO}_{3}\right)_{2}, \mathrm{MgSiO}_{3}$, and the number of auxetics among nano/microtubes from such crystals are increased to six. Variability of Poisson's ratios and Young's modulus of 7-constant rhombohedral crystals and

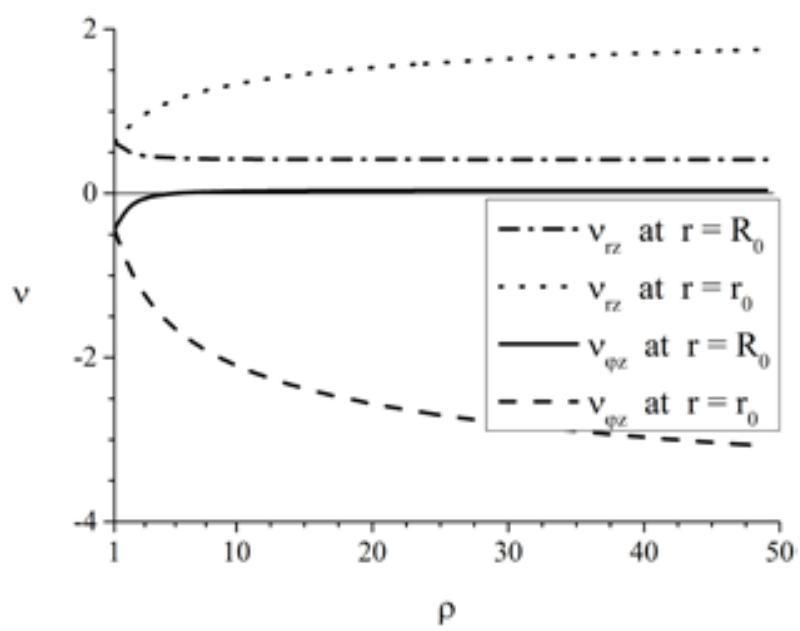

Fig. 2. Dependence of Poisson's ratios on thickness parameter on the surface of the nano/microtubes from the crystal $\mathrm{SbI}_{3}$.

nano/microtubes are analyzed. The dependence of these coefficients and torsional rigidity on the thickness parameter for the nano/microtubes is evaluated.

An important feature of the analysis is that the four basic mechanical characteristics of nano/microtubes from 7-constant rhombohedral crystals (Young's modulus, two Poisson's ratios and torsional rigidity) do not depend on the compliance coefficients $s_{14}^{\prime}, s_{15}^{\prime}$ which are changed with the chiral angle. Such nano/microtubes do not exhibit Poynting's effect. Nano/microtubes from rhombohedral crystals are substantially different by this from nano/microtubes of many other crystals, for example, orthorhombic [27] and tetragonal [28] systems.

Aknowledgements. The work was supported by the Program for the Basic Research IV.11 of the Department of Energetic, Machinery, Mechanics and Control Processes of the Russian Academy of Sciences, and the Grant of the President of the Russian Federation for state support of young Russian scientists MK-5891.2015.1 (L.D.S., V.M.A.).

Table 3. Poisson's ratio for the nano/microtubes.

\begin{tabular}{|c|c|c|c|c|c|c|}
\hline \multirow{2}{*}{ Tubes } & \multirow{2}{*}{$\begin{array}{c}v_{r z} \\
\rho-1 \ll 1\end{array}$} & \multirow{2}{*}{$\begin{array}{c}v_{\varphi z} \\
\rho-1 \ll 1\end{array}$} & \multicolumn{2}{|c|}{$\rho_{c r}$ for $v_{r z}$} & \multicolumn{2}{|c|}{$\rho_{c r}$ for $v_{\varphi z}$} \\
\hline & & & $r=r_{0}$ & $r=R_{0}$ & $r=r_{0}$ & $r=R_{0}$ \\
\hline $\mathrm{SbI}_{3}$ & 0.62 & -0.44 & - & - & - & 5.44 \\
\hline $\mathrm{Be}_{2} \mathrm{SiO}_{4}$ & 0.23 & 0.34 & - & - & - & - \\
\hline $\mathrm{BiI}_{3}(83 \mathrm{~K})$ & 0.31 & 0.10 & - & - & 2.08 & - \\
\hline $\mathrm{Ce}_{2} \mathrm{Mg}_{3}\left(\mathrm{NO}_{3}\right)_{12} \cdot 24 \mathrm{H}_{2} \mathrm{O}$ & 0.27 & 0.37 & - & - & - & - \\
\hline $\mathrm{CaMg}\left(\mathrm{CO}_{3}\right)_{2}$ & 0.33 & 0.34 & - & - & - & - \\
\hline $\mathrm{Pb}_{4.7} \mathrm{Ba}_{0.3} \mathrm{Ge}_{3} \mathrm{O}_{11}$ & 0.15 & 0.34 & 33.1 & - & - & - \\
\hline $\mathrm{Pb}_{5} \mathrm{Ge}_{3} \mathrm{O}_{11}$ & 0.13 & 0.34 & 24.0 & - & - & - \\
\hline \multirow{2}{*}{$\mathrm{Pb}_{5} \mathrm{Ge}_{3} \mathrm{O}_{11}, s^{E}$} & 0.12 & 0.36 & 16.5 & - & - & - \\
\hline & 0.12 & 0.36 & 16.4 & - & - & - \\
\hline $\mathrm{MgSiO}_{3}$ & 0.12 & 0.37 & 24.9 & - & - & - \\
\hline
\end{tabular}


Table 4. Young's modulus of the nano/microtubes.

\begin{tabular}{|c|c|c|}
\hline \multirow{2}{*}{ Tubes } & \multicolumn{2}{|c|}{$E, \mathrm{GPa}$} \\
\cline { 2 - 3 } & $\rho-1 \ll 1$ & $\rho=10$ \\
\hline $\mathrm{SbI}_{3}$ & 9.45 & 11.7 \\
\hline $\mathrm{Be}_{2} \mathrm{SiO}_{4}$ & 260 & 261 \\
\hline $\mathrm{BiI}_{3}(83 \mathrm{~K})$ & 25.1 & 25.3 \\
\hline $\mathrm{Ce}_{2} \mathrm{Mg}_{3}\left(\mathrm{NO}_{3}\right)_{12} \cdot 24 \mathrm{H}_{2} \mathrm{O}$ & 15.9 & 15.9 \\
\hline $\left.\mathrm{CaMg}_{2} \mathrm{CO}_{3}\right)_{2}$ & 142 & 142 \\
\hline $\mathrm{Pb}_{4.7} \mathrm{Ba}_{0.3} \mathrm{Ge}_{3} \mathrm{O}_{11}$ & 56.8 & 57.3 \\
\hline $\mathrm{Pb}_{5} \mathrm{Ge}_{3} \mathrm{O}_{11}$ & 57.1 & 57.7 \\
\hline $\mathrm{Pb}_{5} \mathrm{Ge}_{3} \mathrm{O}_{11}, s^{E}$ & 56.5 & 57.3 \\
\hline $\mathrm{MgSiO}_{3}$ & 55.7 & 56.5 \\
\hline & 385 & 390 \\
\hline
\end{tabular}

\section{References}

1. R.S. Lakes. Science 235 (4792), 1038 (1987)

2. E.A. Friis, R.S. Lakes, J.B. Park. J. Mater. Sci. 23 (12), 4406 (1988)

3. R.H. Baughman, J.M. Shacklette, A.A. Zakhidov, S. Stafstrom. Nature 392 (6674), 362 (1998)

4. S.P. Tokmakova. Phys. Status Solidi B 242 (3), 721 (2005)

5. A. Norris. Proc. Roy. Soc. A 462 (2075), 3385 (2006)

6. T. Paszkiewicz, S. Wolski. Phys. Status Solidi, B 244 (3), 966 (2007)

7. T. Paszkiewicz, S. Wolski. J. Phys., Conf. Ser. 104, 012038 (2008)

8. A.C. Branka, D.M. Heyes, K.W. Wojciechowski. Phys. Status Solidi, B 246 (9), 2063 (2009)

9. R.V. Goldstein, V.A. Gorodtsov, D.S. Lisovenko. Mech. Solids 45 (4), 529 (2010)

10. R.V. Goldstein, V.A. Gorodtsov, D.S. Lisovenko. Doklady Phys. 56 (7), 399 (2011)

11. A.C. Branka, D.M. Heyes, K.W. Wojciechowski. Phys. Status Solidi, B 248 (1), 96 (2011)

12. A.C. Branka, D.M. Heyes, Sz. Mackowiak, S. Pieprzyk, K.W. Wojciechowski. Phys. Status Solidi, B 249 (7), 1373 (2012)

13. R.V. Goldstein, V.A. Gorodtsov, D.S. Lisovenko. Phys. Status Solidi, B 250 (10), 2038 (2013)

14. V.V. Krasavin., A.V. Krasavin. Phys. Status Solidi, B 251 (11), 2314 (2014)

15. R.V. Goldstein, V.A. Gorodtsov, D.S. Lisovenko, M.A.
Table 5. Parameter $\alpha$ of torsional rigidity for the tubes.

\begin{tabular}{|c|c|}
\hline Tubes & $\alpha, \mathrm{GPa}$ \\
\hline $\mathrm{SbI}_{3}$ & 13.3 \\
\hline $\mathrm{Be}_{2} \mathrm{SiO}_{4}$ & 153 \\
\hline $\mathrm{BiI}_{3}(83 \mathrm{~K})$ & 18.0 \\
\hline $\mathrm{Ce}_{2} \mathrm{Mg}_{3}\left(\mathrm{NO}_{3}\right)_{12} \cdot 24 \mathrm{H}_{2} \mathrm{O}$ & 9.13 \\
\hline $\mathrm{CaMg}_{\left(\mathrm{CO}_{3}\right)_{2}}$ & 83.2 \\
\hline $\mathrm{Pb}_{4.7} \mathrm{Ba}_{0.3} \mathrm{Ge}_{3} \mathrm{O}_{11}$ & 33.4 \\
\hline $\mathrm{Pb}_{5} \mathrm{Ge}_{3} \mathrm{O}_{11}$ & 33.6 \\
\hline $\mathrm{Pb}_{5} \mathrm{Ge}_{3} \mathrm{O}_{11}, s^{E}$ & 32.6 \\
\hline $\mathrm{MgSiO}_{3}$ & 32.2 \\
\hline
\end{tabular}

Volkov. Phys. Mesomech 17 (2), 97 (2014)

16. R.V. Goldstein, V.A. Gorodtsov, D.S. Lisovenko. Phys. Mesomech. 12 (1-2), 38 (2009)

17. R.V. Goldstein, V.A. Gorodtsov, D.S. Lisovenko. Phys. Mesomech 13 (1-2), 12 (2010)

18. R.V. Goldstein, V.A. Gorodtsov, D.S. Lisovenko. Doklady Phys. 58 (9), 400 (2013)

19. Landolt-Börnstein. Group III: Crystal and Solid State Physics. 29a. Second and Higher Order Constants. Berlin. Springer (1992)

20. Yu.I. Sirotin, M.P. Shaskol'skaja. Fundamentals of Crystal Physics. Nauka, Moscow (1975)

21. J. Nye. Physical Properties of Crystals. Oxford Univ. Press, Oxford (1985)

22. C.N.R. Rao, M. Nath. Inorganic nanotubes. Dalton Trans 1,1 (2003)

23. R. Tenne. Nature Nanotechnology 1, 103 (2006)

24. S.V. Golod, V.Ya. Prinz, V.I. Mashanov, A.K. Gutakovsky. Semicond. Sci. Technolog. 16 (3), 181 (2001)

25. O.G. Schmidt, N. Schmarje, C. Deneke, C. Muller, N.-Y. Jin-Phillipp. Adv. Mater 13 (10), 756 (2001)

26. Y. Mei, G. Huang, A.A. Solovev, S. Sanchez, E.B. Urena, I. Monch, F. Ding, T. Reindl, K.Y. Fu, P.K. Chu, O.G. Schmidt. Adv. Mater 20 (21), 4085 (2008)

27. R.V. Goldstein, V.A. Gorodtsov, D.S. Lisovenko. Doklady Physics 60 (9), 396 (2015).

28. R.V. Goldstein, V.A. Gorodtsov, D.S. Lisovenko, M.A. Volkov. Phys. Status Solidi, B 252 (7), 1580 (2015) 